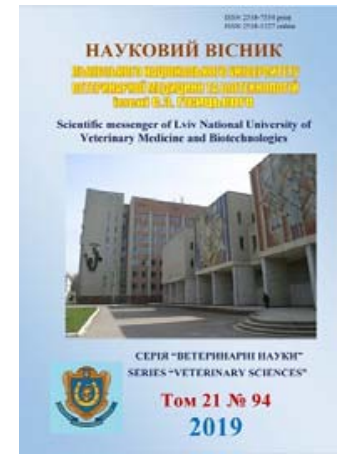

Науковий вісник Дьвівського національного університету ветеринарної медицини та біотехнологій імені С.3. Гжицького.

\author{
Серія: Ветеринарні науки
}

Scientific Messenger of Lviv National University of Veterinary Medicine and Biotechnologies. Series: Veterinary sciences

UDC 578.5/.28:575.856.[543.054:543.635.28]

\title{
A necessity of introduction of the system of registration of GMO is for Ukraine
}

\author{
B.I. Nazar, H.V. Kushnir, H.I. Boiko, S.D. Murska \\ State Scientific-Research Control Institute of Veterinary Medicinal Products and Feed Additives, Lviv, Ukraine
}

\section{Article info}

Received 24.04.2019

Received in revised form 27.05.2019

Accepted 28.05.2019

State Scientific-Research Control Institute of Veterinary Medicinal Products and Feed Additives.

Donetska str., 11, Lviv, 79019, Ukraine. Tel.: +38-067-675-57-81 E-mail:bobnaz@ukr.net

\begin{abstract}
Nazar, B.I., Kushnir, H.V., Boiko, H.I., \& Murska, S.D. (2019). A necessity of introduction of the system of registration of GMO is for Ukraine. Scientific Messenger of Lviv National University of Veterinary Medicine and Biotechnologies. Series: Veterinary sciences, 21(94), 152-156. doi: $10.32718 /$ nvlvet 9428
\end{abstract}

The article presents the main methodological approaches and criteria for the necessity of development and introduction of the State Registration of GMOs sources in Ukraine. The list of analytical researches that are to be carried out at the registration of the GMO source, expert evaluation of GMO identification methods, reproduction of detection methods, identification and quantification of GMOs are given. Submitted and analyzed legislative documents regulating the procedure for registration and control of GMO circulation in the countries of the European Union and Ukraine. DNDKI of veterinary preparations and fodder supplements on the tasks of the State Committee of Veterinary Medicine of Ukraine during 20102018 a number of normative documents were developed regarding procedures related to the use and circulation of feed, feed additives, premixes and veterinary preparations that are composed, containing or made using genetically modified sources in Ukraine: the procedure for state registration, the procedure for carrying out the state veterinary and sanitary examination of GMOs for sources of forage feed additives and veterinary preparations ativ plan state monitoring GMO sources of feed, feed additives, premixes for livestock and poultry. The procedure determines the procedure for state registration of GMOs for sources of feed, feed additives and veterinary preparations containing genetically modified organisms or obtained from their use. It is envisaged that the state register of GMO sources is conducted in the form approved by the State Service of Ukraine for Food Safety and Consumer Protection. On the basis of the analysis, a draft list of feeds, feed materials, protein-vitamin concentrates and premixes that have to be monitored for GMO content has been developed. This project list includes soy, corn, rape and products of their processing, fodder, feed mixes, feed concentrates, etc. In the SSRCI of veterinary drugs and supplements, in 2018, the "Guidelines for identifying the GM soya line (Soybean MON40-3-2) GTS 40-3-2" were developed and approved. "Methodological recommendations are intended to identify the GM soya line (Soybean MON40-3 -2) GTS 40-3-2 (Genetically modified soybean that contains - genetically modified soybean containing (cp4 epsps gene inserted to confer tolerance to herbicide glyphosate) cp4 epsps gene inserted to provide resistance to glyphosate herbicide (glyphosate) in plant material, feed and food products by polymerase chain reaction in real time (PCR-RF)". The qualitative determination of GMOs is based on the discovery of genetically modified (GM) targeted regulatory sequences of the 35S Cauliflower Mosaic Virus (CaMV) promoter or FMV promoter and/or the NOS (T-NOS) T1 terminator of Agrobacterium tumefaciens plasmids that are introduced into the genetic constructs of GM based on the use of the multiplex polymerase chain reaction method to obtain real-time research results $-P C R R F$.

Key words: state registration of GMO of sources, stern, forage additions, premiksi, genetically modified organisms.

\section{Необхідність запровадження системи ресстрації ГМО в Україні}

\author{
Б.І. Назар, Г.В. Кушнір, Г.Й. Бойко, С.Д. Мурська
}

Державний науково-дослідний контрольний інститут ветеринарних препаратів та кормових добавок, м. Львів, Украӥна 
У статті наведено основні методичні підходи та критерії щзодо необхідності розроблення та впровадження в Україні Державної реєстрації джерел ГМО. Подано перелік аналітичних досліджень, які необхідно проводити при реєстрацї ГМО джерела, експертну очінку методів ідентифікації ГМО, відтворення методів виявлення, ідентифікації та кількісного визначення ГМО. Представлено та проаналізовано законодавчі документи, які регламентують прочедуру реєстрачії і контролю обігу ГМО в країнах Євросоюзу та Україні. ДНДКІ ветпрепаратів та кормових добавок за завданням Державного комітету ветеринарної медицини України протягом 2010-2018 років було розроблено ряд нормативних документів шуодо процедур, пов 'язаних із використанням та обігом кормів, кормових добавок, преміксів та ветеринарних препаратів, які складаються, містять або виготовлені із застосуванням генетично модифікованих джерел в Україні: порядок державної реєстрачї, порядок проведення державної ветеринарносанітарної експертизи ГМО джерел кормів кормових добавок та ветеринарних препаратів, план державного моніторингу ГМО джерел у кормах, кормових добавках, преміксах для сільськогосподарських тварин та птиці. Порядок визначає прочедуру державної реєстрації ГМО джерел кормів, кормових добавок та ветеринарних препаратів, які містять генетично модифіковані організми або отриманих з їх використанням. Передбачено, щүо державний реєстр ГМО джерел ведеться за формою, затвердженою Державною службою Украйни з питань безпечності харчових продуктів та захисту споживачів. На основі проведеного аналізу було розроблено проект переліку кормів, кормової сировини, білково-вітамінних концентратів та преміксів, які необхідно контролювати на вміст ГМО. Цей проект-перелік включає сою, кукурудзу, ріпак та продукти їх переробки, комбікорми, кормосуміші, кормові концентрати тощьо. У ДНДКІ ветпрепаратів та кормових добавок в 2018 рочі було розроблено та затверджено "Методичні рекомендачії призначені для ідентифікачії ГМ сої лінї (Soybean MON40-3-2) GTS 40-3-2 (Genetically modified soybean that contains - генетично модифікована соя, яка містить (cp4 epsps gene inserted to confer tolerance to the herbicide glyphosate) cp4 epsps ген вставлений надати стійкість до гербіииду гліфосату (glyphosate) у рослинній сировині, кормах та харчових продуктах методом полімеразної ланцюгової реакиї в реальному часі (ПЛР-РЧ). Якісне визначення ГМО базується на виявленні генетично модифікованих (ГМ) иільових регуляторних послідовностей промотора 35 sірусу мозаїки иввітної капусти (СамV) або промотора FMV $i$ (або) термінатора NOS (T-NOS) T1 плазміди Agrobacterium tuтеfaciens, які вводяться в генетичні конструкції ГМ рослин, щзо базується на використанні методу мультиплексної полімеразної ланцюгової реакції з отриманням результатів досліджень в режимі реального часу - ПЛР РЧ.

Ключові слова: державна реєстрачія ГМО джерел, корми, кормові добавки, премікси, генетично модифіковані організми.

\section{Вступ}

Процедуру реєстрації ГМО в Європейському Союзі регламентують два законодавчих акти ЄС:

1. Директива 2001/18/ЕС про свідомий випуск у навколишне середовище генетично модифікованих організмів (положення частини С Директиви), що регулює розміщення ГМО на ринку для культивації, ввезення та переробки в промислові продукти;

2. Регламент 1829/2003 про генетично модифіковані продукти харчування та корми, що регулює розміщення на ринку ГМО для використання в продуктах харчування та в кормах, а також ГМ продукти харчування та корми, що містять, складаються чи виробляються з ГМО для культивації, ввезення та переробки на харчові продукти або корми.

Якщо харчові продукти або корми містять чи складаються з ГМО, заява на отримання дозволу подається відповідно до Регламенту 1829/2003. Тоді екологічна експертиза ризику, згідно з Директивою 2001/18/EC, виконується одночасно з оцінкою безпеки харчових продуктів та кормів.

Для реєстрації насіння в ЄС спочатку відповідна ГМ рослина, згідно з Директивою 2001/18/ЕС, повинна пройти реєстрацію. Лише після цього сорти насіння, отримані $з$ цієї ГМ рослини, можуть подаватися для затвердження в державах - членах СС. 3 цією метою проводиться випробування, але питання безпеки продукції не підлягають розгляду, оскільки дані процедури виконувались під час затвердження ГМО на рівні ЄС. Після затвердження та внесення до національного реєстру сортів рослин сорт підлягає комерційному використанню в межах даної держави члена $Є$. Тільки за умови внесення його за рішенням Європейського Комісії до Спільного реєстру ЄС сортів сільськогосподарських рослин він може використовуватися на всій території $€$ С.
Схема реєстрації ГМО в СС включає такі етапи:

- Згідно $з$ Директивою 2001/18/ЕС заява подається на розгляд до уповноваженого органу в державі члені $Є С$, де ГМО вперше виводиться на ринок. Заява повинна містити інформацію, передбачену Статтею 13 Директиви, включаючи експертизу екологічного ризику, що виконується заявником.

- Інформація розглядається органом відповідно до Директиви. Протягом 90 днів 3 моменту отримання заяви приймається рішення у вигляді звіту про перевірку та відправляється заявникові.

- Якщо звіт позитивний, він надсилається відповідним національним органом разом із заявою до Європейської Комісії, яка протягом 30 днів надсилає далі цю інформацію до відповідних органів інших держав-членів.

- Упродовж 60 діб Комісія та відповідні національні органи мають право вимагати додаткової інформації, надавати коментарі та вносити заперечення щодо розміщення на ринку даного ГМО.

- Крім того, завдання Комісії - забезпечити відкритий доступ до звіту про перевірку для громадського обговорення протягом 30 діб.

- Якщо Комісія чи інші держави - члени $Є С$ не мають жодних заперечень, орган, що виконував експертизу, надає письмове погодження для розміщення на ринку відповідного ГМО. Дозвіл $\epsilon$ дійсним протягом десять років та може бути продовжений за певних умов на наступні десять років. Усі продукти, отримані із зареєстрованих у встановленому порядку ГМ рослин, підлягають обов'язковому маркуванню.

- Усі заперечення та застереження щодо конкретного ГМО обговорюються під час погоджувального процесу за участі держав - членів СС, Комісії та заявника. Якщо питання узгоджуються в межах 105 діб з початку розгляду звіту про перевірку, орган, що 
здійснював перевірку, видає письмовий дозвіл на розміщення на ринку відповідного ГМО.

- Для отримання дозволу на реалізацію ГМО, згідно з Регламентом СС 1829/2003, компанія повинна подати заяву до уповноваженого органу держави члена $\mathrm{CC}$, в якій продукт уперше виводиться на ринок.

- У заяві повинні бути надані відомості, передбачені Статтею 5 (3) Регламенту, а також документальне підтвердження того, що даний продукт: 1) не шкодить здоров'ю людей, тварин чи навколишньому середовищу; 2) не вводить в оману споживачів; 3) не відрізняється від тих продуктів харчування, на заміну яких він спрямовується, за поживною цінністю за умови нормального рівня споживання.

- Агентство надає свій експертний висновок Свропейській Комісії, державам-членам та заявнику, включаючи звіт 3 оцінкою продукту та його обгрунтування, а також оприлюднює його для публічного обговорення.

- Протягом трьох місяців 3 моменту отримання експертного висновку Агентства, Європейська Комісія зобов'язана розробити проект рішення щодо надання дозволу чи відхилення заяви та подати його Постійному комітету 3 харчових продуктів та здоров'я тварин (Dyrektyva 2001/18/EC; Rehlament 1829/2003; Rehlament YeS 882/2004).

У країнах Євросоюзу для уніфікації методики перевірки генетично модифікованих організмів прийнята схема, яка передбачає загальні характеристики організму-донора та організму-реципієнта, оцінку композиційної еквівалентності, оцінку безпечності білків, що кодуються цільовими генами (токсичність, алергенність), оцінку харчової якості на лабораторних тваринах.

Головну інформацію, яка характеризує якість та безпечність генетично модифікованих продуктів, отримують у процесі проведення медико-біологічної оцінки, яка включає у себе визначення композиційної еквівалентності, хронічної токсичності харчового продукту (згодовування генетично модифікованих продуктів лабораторним тваринам протягом 6-ти місяців) та проведення спеціальних досліджень (алергенність, нейротоксичність, генотоксичність, мутагенність, канцерогенність, вплив на імунний статус і репродуктивну функцію). У комплексі досліджень хронічної токсичності визначають біохімічні, гематологічні та морфологічні показники, малонового альдегіду, а також, активності ферментів 1-ї і 2-ї фази біотрансформації ксенобіотиків (цитохром Р450, цитохром b5, ацетилестераза, епоксигідролаза, глюкуронозилтрансфераза, глутатіонтрансфераза), лізосомальних ензимів (арилсульфатази А $\mathrm{i}$ B, $\beta$ галактозидаза, $\beta$-глюкуронідаза) і ферментів системи антиоксидантного захисту (глутатіонредуктаза, глутатіонпероксидаза, каталаза, супероксиддисмутаза).

При технологічній оцінці досліджують фізикохімічні та органолептичні властивості, технологічні параметри продукціїі. Якщо модифікований продукт харчування або корм для тварин передбачається ви- користовувати у значних кількостях (понад 15\% раціону), додатково можуть проводитися дослідження харчової та кормової цінності продукту, перетравності, впливу на мікрофлору кишечника.

Одним 3 важливим чинників перевірки якості генетично модифікованих продуктів, який на даний час ще не отримав достатнього впровадження, є оцінка значно віддаленого їх впливу на організм споживачів. Питання віддалених впливів, як і хронічні зміни за тривалого споживання не шкідливих при стандартній оцінці генетично модифікованих продуктів і кормів на організм людини і тварин, вивчене на даний час недостатньо. Це викликано причинами медичного, статистичного та етичного характеру. На відміну від дослідів на лабораторних тваринах при оцінці впливу генетично модифікованих продуктів на людей неможливо врахувати вид та кількість спожитої продукції. Крім того, споживачі відрізняються за станом здоров'я, віком, способом життя. Висновки у таких випадках формуються за кількістю реалізованої у даному населеному пункті трансгенної продукції та інформацією про стан здоров'я його мешканців порівняно з жителями інших регіонів. Зрозуміло, що результати таких досліджень недостатньо вірогідні.

\section{Результати та їх обговорення}

ДНДКІ ветпрепаратів та кормових добавок за завданням Державного комітету ветеринарної медицини України протягом 2010-2018 років було розроблено ряд нормативних документів щодо процедур, пов'язаних із використанням та обігом кормів, кормових добавок, преміксів та ветеринарних препаратів, які складаються, містять або виготовлені із застосуванням генетично модифікованих джерел в Україні: порядок державної реєстрації, порядок проведення державної ветеринарно-санітарної експертизи ГМО джерел кормів кормових добавок та ветеринарних препаратів, план державного моніторингу ГМО джерел у кормах, кормових добавках, преміксах для сільськогосподарських тварин та птиці (Kotsiumbas et al., 2010).

Порядок визначає процедуру державної реєстрації ГМО джерел кормів, кормових добавок та ветеринарних препаратів, які містять генетично модифіковані організми або отриманих з їх використанням (далі ГМО джерела). Передбачено, що державний реєстр ГМО джерел ведеться за формою, затвердженою Державною службою України з питань безпечності харчових продуктів та захисту споживачів. Інформація, що міститься в Реєстрі, є офіційною інформацією щодо затвердженого переліку ГМО джерел і розміщується на офіційному веб-сайті Державної служби України та публікується в засобах масової інформації i надається безоплатно на запит юридичних і фізичних осіб. Подано перелік аналітичних досліджень, які необхідно проводити при реєстрації ГМО джерела: експертну оцінку методів ідентифікації ГМО, відтворення методів виявлення, ідентифікації та кількісного визначення ГМО, оцінку еквівалентності за результа- 
тами порівняння хімічного складу ГМО джерела 3 хімічним складом його традиційного аналога.

Визначено, що після проведення досліджень якості та безпеки ГМО джерел кормів, кормових добавок та ветеринарних препаратів або отриманих з їх використанням проводиться оцінка ризику небезпеки ГМО об'єктів реєстрації для здоров'я тварин та людей або навколишнього природного середовища при цільовому використанні, а також у разі порушень умов використання. Встановлено порядок оформлення висновку ветеринарно-санітарної експертизи.

На основі проведеного аналізу було розроблено проект переліку кормів, кормової сировини, білкововітамінних концентратів та преміксів, які необхідно контролювати на вміст ГМО. Цей проект-перелік включає сою, кукурудзу, ріпак та продукти їх переробки, комбікорми, кормосуміші, кормові концентрати тощо. Було розроблено, затверджено та впродовж 2010-2017 років виконувався план моніторингу кормів на вміст ГМО. Виконання цього плану було доручено ДНДКІ ветпрепаратів та кормових добавок.

Проте перелічені документи не в повній мірі регулювали обіг ГМО в Україні. Тому для можливого використання генетично модифікованих організмів при годівлі тварин було прийнято Закон України №2264-VIII від 21.12.2017 року “Про безпечність та гігієну кормів.”. Цей закон визначає правові та організаційні засади гарантії безпечності кормів у процесі їх виробництва, обігу та використання, зокрема встановлює вимоги щодо гігієни, маркування, пакування та представлення кормів, регулює відповідні суспільні відносини між операторами ринку та органами державної влади.

Для того, щоб цей закон запрацював, необхідно розробити та затвердити, або взяти за основу Європейські підзаконні документи і головний з них - це “Реєстр генетично модифікованих організмів". Для внесення ГМО в реєстр необхідно мати розроблені “Схеми оцінки генетично модифікованих організмів", ключове місце в яких посідає саме ідентифікація ГМ джерела.

В Україні Державною ветеринарною та фітосанітарною службою в 2013 році терміном на 5 років було зареєстровано одну ГМ-лінію соєвого шроту, а саме MON 40-3-2 (Glycine max, Roundup Ready soybean), що надавало змогу його вільного переміщення та транспортування по території України.

У ДНДКІ ветпрепаратів та кормових добавок в 2018 році було розроблено та затверджено "Методичні рекомендації призначені для ідентифікації ГМ сої лінії (Soybean MON40-3-2) GTS 40-3-2 “Методичні рекомендації призначені для ідентифікації ГМ сої лінії (Soybean MON40-3-2) GTS 40-3-2 (Genetically modified soybean that contains - генетично модифікована соя, яка містить (cp4 epsps gene inserted to confer tolerance to the herbicide glyphosate) cp4 epsps ген вставлений надати стійкість до гербіциду гліфосату (glyphosate) у рослинній сировині, кормах та харчових продуктах методом полімеразної ланцюгової реакції в реальному часі (ПЛР-РЧ).
Якісне визначення ГМО базується на виявленні генетично модифікованих (ГМ) цільових регуляторних послідовностей промотора $35 \mathrm{~S}$ вірусу мозаїки цвітної капусти (CaMV) або промотора FMV і (або) термінатора NOS (T-NOS) T1 плазміди Agrobacterium tumefaciens, які вводяться в генетичні конструкції ГМ рослин, що базується на використанні методу мультиплексної полімеразної ланцюгової реакції з отриманням результатів досліджень в режимі реального часу - ПЛР РЧ.

Для ідентифікації лінії ГМО використовують праймери і зонди, які розроблені європейською організацією “Об”єднання Арбітражних лабораторій по ГМ продуктах і кормах" і рекомендовані для використання лабораторіями ЄС. Для ідентифікації ліній GTS 40-3-2 використовується специфічна ділянка, що ампліфікує ділянку ДНК між 3- кінцем ГМ конструкції і геномом сої.

Однак безпосереднє сусідство України з Росією, Білорусією, Польщою, Румунією, Туреччиною, які офіційно дозволили використання на своїх територіях ГМО та продукти, що містять їх у своєму складі, дають підстави припустити, що на внутрішньому ринку України продовжують розповсюджуватися інші лінії трансгенної сої, які не дозволені на нашій території. Тому важливим етапом дослідження наявності ГМО є ідентифікація ГМ-ліній, оскільки вона дає змогу зрозуміти, які саме лінії тієї чи іншої ГМ-рослини є в обігу на аграрному ринку.

В 2019 році нами заплановано розробити та затвердити методичні рекомендації, призначені для ідентифікації ГМ сої лінії Soybean "MON89788"(Genetically modified soybean that contains). Генетично модифікована соя, яка містить (cp4 epsps gene inserted to confer tolerance to the herbicide glyphosate) cp4 epsps ген, вставлений надати стійкості до гербіцидів glyphosate. На перспективу ми плануємо розробити "Методичні рекомендації, призначені для ідентифікації ГМ сої лінії Soybean A270412 (Genetically modified soybean that contains).

\section{Висновки}

Впровадження реєстрації ГМО джерел у кормах дозволить забезпечити інформованість 3 метою подальшого забезпечення охорони здоров'я людини, тварин і навколишнього природнього середовища, створить умови для безпечного практичного використання ГМО в господарських цілях, зможе запобігти неконтрольованому використанню ГМО-джерел в кормах.

\section{References}

Dyrektyva 2001/18/EC "Pro navmysnyi vypusk u navkolyshnie seredovyshche henetychno modyfikovanykh orha-nizmiv (polozhennia chastyny S Dyrektyvy)". http://online.budstandart.com/ua/catalog/ doc-page.html?id_doc $=67434$ (in Ukrainian). 
Rehlament 1829/2003 "Pro henetychno modyfikovani produkty kharchuvannia ta kormy" (in Ukrainian).

Rehlament YeS 882/2004 "Pro ofitsiinyi kontrol dlia harantuvannia vidpovidnosti kormiv vymoham zakono-davstva, sanitarii ta blahopoluchchia tvaryn" (in Ukrainian).
Kotsiumbas, I.Ia., Levytskyi, T.R., Nazar, B.I., \& Kushnir, H.V. (2018). Tvarynnytstvo sohodni (Animal industry today) Normatyvno-pravovi osnovy obihu henetychno modyfikovanykh orhanizmiv v Ukraini, 9, 4-9 (in Ukrainian). 